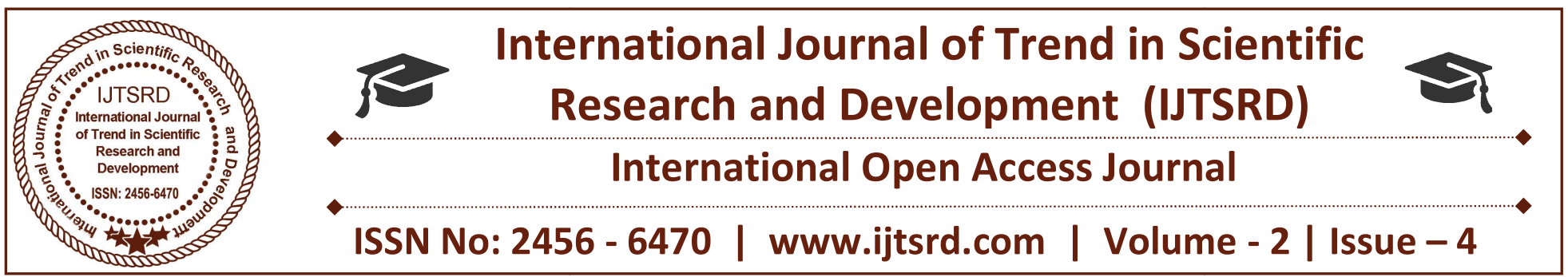

\title{
Justly Balanced Community: Concept, Principles and Aims
}

\author{
Dr. Burhan Rashid \\ Assistant Professor, Shah-I-Hamadan Institute of Islamic Studies, \\ University of Kashmir, Jammu Kashmir, India
}

\begin{abstract}
All the teachings which Islam gives and instructs are in full conformity with the human nature. They are applicable in all situations and circumstances. There is no excesses or deficiencies found in them. One who acts according to the teachings of Islam is basically acting according to what nature demands of him. Thus in this way, he is fulfilling the genuine demands of the nature on the one hand, and is simultaneously gaining the pleasure of the Lord of the universe on the other hand.
\end{abstract}

The present paper deals with the explanation of how Islam and its principles steer clear of the extremes in all matters of human life. Many examples have been cited to illustrate how the teachings of Islam are free from all kinds of excesses and deficiencies. Light is also thrown on the importance of justly balanced community; its principles, aims, duties, objectives and purpose.

Keywords: Justice, Moderation, Universality, Applicability. Excess and Deficiency (Ifrāt and Tafrit), human life, equilibrium.

\section{INTRODUCTION}

Life, according to Islam, is an indivisible whole. All its aspects (and activities) whether political or economic, social or religious, local or international are to be governed and controlled by Divine Law. This leads to social solidarity or edifice parts of which strengthen each other. The outstanding feature of Islamic life is that it is free from extremes and is justly balanced, for virtue is to avoid the extremes on either side. The message of the Lord is:

We have moulded you (O! Muslim community) [1] into a society justly balanced (in every respect) that ye might be a pattern (or witness) unto others (i.e., the rest of mankind), even as the Prophet has been a pattern unto you. \{Al-Quran, Surah al-Baqarah, Chapter 2:143\}.

At another place Allah says:

And of those whom We have created there is a community guiding others with truth (i.e., in accordance with the True Religion) as by it they act justly. \{Al-Quran, Surah al-A'rāf, Chapter 7:181\}.

The qualities of a moderate / justly balanced community are candidly expressed in a number of Quranic $\bar{A} y \bar{a} t$ (verses). The holy Quran also alludes to the aims and duties of such a balanced community. It says that the best community among the mankind is that which enjoins what is right and forbids what is wrong. [2]

Islam, thus, steers clear of the extremes in life and chooses for itself the middle path or the principle of moderation. Here, it may be said that in one sense this is the same as the 'Golden Mean' of Aristotle. But there is a difference between 'the moderation (or mean)' as a principle and 'the mean' of Aristotle which he put forward as a rule. A rule is not a special order or command; it fluctuates with the collateral circumstances of each situation and is subject to flexible reason, while a principle is the command, not variable but to be obeyed by all. In Islam it takes the form of Law rather it is the Law itself. Islamic Law, not given to extremes, is no other than the Law which adheres to the middle course and moderation in life. Muhammad Asad says:

Moral knowledge, according to the teachings of Islam, automatically forces a moral responsibility upon men. A mere Platonic discernment between 
Right and Wrong, without the urge to promote the Right and to destroy the Wrong is a gross immorality in itself. In Islam, morality lives and dies with the human endeavor to establish its victory upon earth. [3]

To illustrate the doctrine of moderation in Islam, let us see some examples of how Islam adopts the middle path in all matters, be they with regards to belief, worship, mutual dealings, transactions, social behavior, morals or manners.

\subsection{Moderation in the matters pertaining to beliefs (İmāniyāt)}

In the earlier nations, we see that on the one hand some took their Prophets as the sons of God and started adoring and worshipping them. Regarding Jews and Christians, the holy Quran says:

And the Jews say: 'Uzayr [4] is a child (or son) of God; and the Christians say: Masīh [5] ('Isā') is a child (or son) of God. That is their saying with their mouths (i.e., unsupported by their own prophets), resembling the saying of those who disbelieved aforetime. Allah confound them! Whither are they turning away? \{Al-Quran, Surah al-Taubah, Chapter 9: 30$\}$.

While some others, in spite of seeing multitudes of miracles happening at the hands of their Prophets refused to accompany them in accomplishing the most important tasks. When Mūsā' (A.S.) [6] commanded his people to be strong and courageous to enter the land of Amalekites (the country of Canaan) to conquer it, they rejected his call as is quoted in the holy Qur'ān:

Yet the people said: O Mūsā'! Certainly we shall never march to it so long as they remain there, go forth thou and thy Lord, and fight you twain, we remain here sitting. \{Al-Quran, Surah al-Mā'idah, Chapter 5: 24\} . [7]

There were others who mocked, vexed, injured and even killed their Prophets as is mentioned in the holy Qur'ān. Allah says: "Ah the misery of Our bondmen! There comes not to them any messenger of Ours but him they have been mocking. \{Al-Quran, Surah Yāsīn, Chapter 36:30\}."
Regarding the behavior of the disbelievers of the past nations and their vexation against their Prophets, Allah quotes Mūsā' (A.S.) as saying:

And recall when Mūsā' (vexed at the exhibition of constant rebellion and disobedience among his people) said to his people: my people! Why do you hurt me when you know surely that I am Allah's messenger to you? \{Al-Quran, Surah al-Ṣaff, Chapter $61: 5\}$.

Some of the people of the past nations even killed their prophets; Allah says in the holy Quran: "They (i.e., Jews) have been denying the signs of Allah and killing the prophets of Allah without right. \{AlQuran, Surah Āl-i 'Imrān, Chapter 3:112\}."

But the attitude of this Community / Ummah (i.e., Ummat-i-Muslimah), on the other hand, is and has remained always in moderation with respect to the matters pertaining to beliefs (Imāniyāt). They hold their Prophet, Prophet Muhammad (S.A.A. ${ }^{W} . S$ ) [8] dearest to all; their lives, wealth, progeny, honour and everything. And on the other hand, they recognize Prophet as a Prophet, and God as God; neither raising the prophets to the pedestal of God, or His like, nor degrading God to the level of human beings.

Islam correctly defines the status of the Prophets. It explains that the Prophets were neither God, nor His likeness, nor His sons, nor yet His kinsmen, for they were mortals like all other men. But, despite the fact that they were human beings, they were not like ordinary mortals since they enjoined the privilege of conversing with God, were recipients of Divine Revelations and were free of all sins. As perfect guides of humanity they were a witness to these realities of the celestial realm which are beyond the ken of human perception. They are the assured ones, having wisdom and faith and guidance from the Lord of the worlds. Every man is thus duty-bound to obey and pay his regards to these truthful souls who are raised to preach the Message of God to their fellow beings.

This is the path of moderation --- the path avoiding the excesses of undue veneration and denial of the respect due to the prophets and founders of religions -- which Islam shows to the world as a necessary adjunct to its higher concept of the Unity of God.

\subsection{Moderation in matters of worship}


After 'belief' comes the number of worship / acts of devotion, here again we see that Islam has corrected all the earlier misconceptions of extremities. This is briefly illustrated in the following lines.

Worship was, and still is, a fundamental discipline of every religion. The people of past nations had, however, mistaken self-torture for veneration of God. They had somehow convinced themselves that the more one suffers agony and subjects one's body to suffering and pain, the more one advances spiritually towards piety and purity of soul. Therefore, falling prey of these misconceived notions, they had taken to strange practices, took different forms of selfmortification which they considered the doors to spiritual elevation. Therefore, some of them refrained from taking baths throughout their lives, some clad themselves in tatters or tunics made of coarse material (like hemp), some remained unclad even during freezing cold season, some had taken a vow to remain standing for the rest of their lives, some lived in the deserted dens of wild beasts, some always remained in the sun, some dwelt on bare rocks, some ate only leaves of the trees, some scrupulously avoided contact with women and some even hanged themselves upside down from the trees. These ways of worshipping God were deemed highly meritorious all over the West during the dark ages. Other countries of the world were no better, either.

On the other hand, we see some other nations of yore used to sell the commandments and words of the Lord for worldly gains. Their religious scholars and priests gave wrong verdicts (Fatāwa $)$ by taking bribes. They distorted and deliberately misinterpreted the teachings of their Prophets and the scriptures. They were always in search of pretexts and excuses in order to remain away from the acts of worship.

It was in this atmosphere, prevailing throughout the world, that Islam came to set a middle path between these two extremes. Islam, on the one hand, delivered humanity from these fiendish practices by telling it that self-torture and bodily exertions were neither demanded by God nor they led to the union of the devotee's spirit with the Supreme Being. Islam candidly rejects the concept of monasticism. Allah says: "And asceticism (or, monasticism, or monkery). We did not prescribe it for them; they innovated it, only seeking Allah's goodwill, but they tended it not with the tendence due to it. AAl-Quran, Surah alHadid, Chapter 57:27\}." [9]
And Prophet Muhammad (S.A.A. ${ }^{w}$.S.) has said: "There is no monasticism in Islam."

On the other hand, Islam cultivated such spirit of servitude (devotion to God) in its followers that they never compromised with it and endeavoured to make it dominant over all the spheres of their lives. Islam put the conception of devotion on true and right lines by telling that the spirit of worship lies in the acknowledgment of complete and unquestioned loyalty to the Lord, the Master of the Worlds.

Maulānā Abdul Majid Daryābādī writes:

Islam ... does not base its system of religio-moral perfection on the conception of the wickedness and sinfulness of the human body; and the law of Islam does not repudiate the earthly life in toto as intrinsically impure. It does not demand the suppression of fleshly impulses; it only requires that they should be curbed and controlled in accordance with the norm supplied by itself. Celibacy on a large scale is designed to defeat the very aim and purpose of nature --- the replenishment of the earth. [10]

\subsection{Moderation in matters of almsgiving and charity}

Although almsgiving and charity is considered as an act of great virtue in all the religions but they have not remained free of extremes with regards to it. On the one hand, we see that the teaching of Bible regards it the greatest virtue to spend everything in charity and become impoverished and destitute himself. Bible exhorts its followers to sell all they have and give the money to the poor (so as to become penniless and pauper himself).

On the other hand, there is a class of people who are never moved to spend anything in the way of God. They resort to different pretexts and excuses to exempt themselves from spending in the way of God. Qur'ān makes mentions of such people as under:

And when it is said to them: expend (in alms and charity) of that with which Allah has provided you, those who disbelieve say to the faithful: shall we feed those whom Allah Himself would have fed, had He willed? You are but in error manifest. \{Al-Quran, Surah Yāsīn, Chapter 36:47\}

Islam adopted the middle path, free of both the extremes, in this matter as well. Firstly, it made the 
concept of almsgiving and charity clear and vivid by giving complete details of all its elements. Secondly, it did not command its followers to spend each and everything in almsgiving so as to fall into impoverishment, instead it says:

And they ask thee (O Muhammad!) as to what they shall spend (in voluntary charity). Say thou: "Redundant portion (i.e., whatever can be spent without detriment to the necessities of one's own self or of those whose maintenance is obligatory on him.) \{Al-Quran, Surah al-Baqarah, Chapter 2: 219\}.

At another place Allah says:

Let not your hand be chained to your neck, nor stretch it forth to its extremity (i.e., do not be either niggardly or profuse, but observe the mean between the two extremes.) lest you sit down reproached. (Al-Quran, Surah al-Isrā', Chapter 17: 29\}.

When 'Umar (Rad.A) [11] approached the Prophet (S.A.A. ${ }^{w} . S$.) and asked his opinion as to giving away, in charity, his best garden in Khyber, the Prophet advised him to keep the garden for himself and give away only its produce in charity. This proves that regard for others does not mean disregard for the self. The self is to be cared for and developed so that it may be of greater service to others. But this does not mean unrestrained development of self nor does it mean self-destruction but a careful development bearing in mind one's duties to others.

It is the reason that Islam, by way of Ithar (unselfishness), also exhorts its followers to give preference to others who are in more need than yourselves. Islam also instructs that charity should be given only with utmost sincerity; only to seek the pleasure of the Lord, not for the worldly gains, display, showoff and ostentation. Neither should there be any intention to hurt the sentiments of the receiver, or to put any burden upon him. The holy Qur'ān has quoted the behaviour of Ansār (Helpers at Madinnah) with the Muhājirūn (Emigrants from Makkah) as praiseworthy as they had offered full help to them. Allah says: "Preferring them (Muhājirūn) above themselves even though there was want among them (Ansār). \{Al-Quran, Surah al-Isrā', Chapter 59: 9\}." They themselves were thirsty and hungry but they, in the spirit of self-sacrifice, offered whatever they had to the Muhajiirūn (Emigrants from Makkah) and proved ideal hosts to them.
Those who feed the hungry, orphans, destitute and captives etc. are praised by Allah. Allah says: "And they feed, for love of Him, with food the destitute, the orphan and the captive. \{Al-Quran, Surah al-Insān, Chapter 76: 8 \}"

Regarding the sincerity of thought and avoiding any kind of display and ostentation, and maintaining kindly feelings towards the receiver, the holy Quran says:

O you who believe! Void not your charities by taunt and by harm, like unto him who spends his riches to be seen of men. \{Al-Quran, Surah al-Baqarah, Chapter 2: 264$\}$.

At another place, Allah says: "an honourable word (of refusal) and forgiveness (granted to the beggar if he is wantonly insolent) are better (a thousand times) than an alms followed by injury. \{Al-Quran, Surah alBaqarah, Chapter 2: 263 \}."

The whole phrase means: 'Refusal with pleasing or gracious speech and prayer expressed to the beggar that God may sustain him, and forgiveness granted to the beggar for his importunity ... are better than an alms with annoyance followed by reproach for a benefit conferred and for begging.'

\subsection{Moderation regarding the behaviour with menstruating women}

The Biblical regulations concerning menstruating women are much rigid. According to Bible:

She shall be put apart for seven days: and whosoever toucheth her shall be unclean until the even. And everything that she lieth upon in her separation shall be unclean: everything also that she sitteth upon shall be unclean. And whosoever toucheth her bed shall wash his clothes, and bathe himself in water, and be unclean until the even.'(Leviticus: The Third Book of Moses 15:19-21). [12]

Still more rigid are the laws prescribed by the Jewish doctors. According to them:

The woman must reckon seven days after the termination of the period. If then, this lasts seven days; she cannot become pure until the fifteenth day. Purification, furthermore, can be gained only by a ritual bath; and until the woman has taken this, she 
remains unclean....in addition to all this, a woman who does not menstruate regularly is unclean for a certain time before she becomes aware that the period has begun, and objects which she touches are defiled.' (The Jewish Encyclopedia, IX, p. 301). [13]

There are many other communities in whom a menstruating woman has to, according to their code, refrain from all household duties, especially from the preparation of food, and to approach her is often an offence. She must, like the leper of the medieval times, wear a special garment, or call aloud to warn all who approach her that she is unclean. [14]

This is one extreme, the other extreme is that there are others who do not even consider it any filth and pollution but unhesitatingly have intercourses with their wives in the period of their menstruation. They do not even take heed of its biological harms and dreadful consequences out of their extreme zeal of carnal pleasures and uncontrolled sexual desires.

The Qur'ānic injunction regarding this matter is given in the following $\bar{A}$ yah (verse):

And they ask thee (O Prophet!) of menstruation (and cohabitation in that period). Say thou: "it is pollution, so keep away from women during menstruation (i.e., do not cohabit with them during this period), and go not in unto them till they have cleansed themselves. Then when they have thoroughly cleansed themselves (of menstrual pollution, and have washed themselves) go in unto them as Allah has directed you (i.e., in a way that is natural, lawful and clean). Surely Allah loves the repentants, and He loves the cleansers of themselves. \{Al-Quran, Surah al-Baqarah, Chapter 2: $222\}$

It follows from this $\overline{A y a h}$ (verse) that it is only the cohabitation which is prohibited during the period when one's wife is passing through the period of menstruation. In household matters neither is she refrained from performing her duties nor the things she touches, are considered as defiled and unclean.

\subsection{Moderation with regards to the matters of divorce}

The course of divorce or the dissolution of the marriage tie, among ancient nations has been erratic, some making it too loose, others making it too tight. Speaking sociologically, every religion has to meet two ends in the sphere of marriage and family --- to raise the standard of morality and to sanctify the marriage contract. But in practice some religions have become too lenient, others too rigid. The Jewish law takes treats it as a matter of no great concern. If husband finds 'some uncleanness in her; then let him write her a bill of divorcement, and give it in her hand, and send her out of his house. And when she has departed from his house, she may go and be another man's wife.'(Deuteronomy: 24:1, 2). Christianity, on the other hand, taking its stand on the reported saying of Jesus: "what therefore God hath joined together, let not man part asunder......whosoever shall put away his wife, and marry another, committeth adultery against her. (Gospel according to St. Mark 10: 9, 11), and also upon the dictum of Paul: 'let not the wife depart from her husband.' (Paul's First Epistle to the Corinthinians; 7:10), has interdicted divorce altogether. The Catholics hold: 'when the sacrament of matrimony has been received by a man and a woman and ratified by their cohabitation as husband and wife, their union cannot be dissolved except by death.' (New Catholic Dictionary, p.no. 477). The climax was reached in the rules of Roman Catholic Church... (It) 'Treats marriage as a sacrament, and demands indissolubility and non-changeability. This in itself is unreasonable. Judaism takes account of the mutability of human feelings, and free people when the chains of matrimony become fetters; but the Catholic Church refuses to recognize any such change of feeling. The bonds of matrimony become a chain as heavy and galling as iron in which two people must languish for the term of their natural lives.' The Protestants allow it no doubt, but only on such grounds as are of comparatively rare occurrence --fornication, for instance.

Islam has steered its course midway between the two, avoiding the extremes of either making divorce too rigid or banning it altogether, or of making it too loose and frivolous. Islam has adopted the only wise course open --- that of imposing certain conditions and limitations upon the right of the husband to dissolve the matrimonial bond, the object of which is 'to ensure that the husband does not act in haste or anger and that separation becomes inevitable in the interests of the husband and wife and the children.' ... divorce, though perfectly legitimate in itself, is not to be had recourse to light-heartedly or on flimsy grounds. There are verses, in Qur'ān, which tend to discourage the practice, unless, of course, there be strong reasons for taking the step, or the incompatibility of temperaments be well-established. 
The Prophet $\left(S . A . A .^{W} . S\right)$ is also reported to have observed: _ 'Of all the permissible acts, divorce is the most disapproved of by Allah.'....the goal of matrimony in Islam is to unite two lives, to bring happiness to the couple, and to instill mutual amity, harmony, responsible co-partnership and good fellowship in the pair. Now, human nature being what it is, it sometimes happens that even with the best of motives and after repeated trials, the union remains unhappy. The only remedy then is to unfasten the wedding-tie. Even then, the husband is enjoined by the Qur'ān not to dismiss the wife in disgrace, or with a view to humiliating her but to let her off kindly, with due regard to his chivalry and her tenderness, and with a view to securing peace of mind both for her and himself. [15]

\subsection{Moderation in other matters of the human life}

In addition to the above discussed matters there are numerous other such matters in which other religions have taken one or the other extremities but Islam adopted and showed humanity the path which is balanced and free from all extremes. For example, regarding the manner of spending on one's needs the holy Qur'ān says:

And squander not in squandering; truly the squanderers are the brethren of the devils, and the Devil is ever ungrateful to his Lord. \{Al-Quran, Surah al-Isrā, Chapter 17:26-27\}.

At another place, enumerating the noble qualities of true believers, and His loyal slaves, Allah says:

And those who when they expend, are neither extravagant nor stingy; and it (i.e., their mode of spending) is a medium in between. (Al-Quran, Surah al-Furqān, Chapter 25:67\}

Thus the Quranic instructions on the one hand restricts one from being niggardly, and on the other hand it does not permit to be extravagant and squanderer.

With regards to the manner of walking on the earth, Qur'ān says:

And be thou modest in thy gait (neither going too slowly nor too quickly). \{Al-Quran, Surah Luqmān, Chapter 31:19\}

With regards to maintaining moderation in the voice during speaking and talking, Qur'ān says: and lower thy voice; for the harshest of sounds without doubt is the braying of the ass. \{Al-Quran, Surah Luqmān, Chapter 31:19\}

Even during the worship and acts of adoration the voice should remain moderate; it should neither be raised too high nor should it be dropped too low, though during supplication low voice is recommended. Allah says:

Neither speak thy Prayer aloud, nor speak it in a low tone, but seek a middle course between. \{Al-Quran, Surah al-Isrā, Chapter 17: 110\}.

Call on your Lord with humility and in private: for Allah loveth not those who trespass beyond bounds. \{Al-Quran, Surah al-A'rāf, Chapter 7: 55\}.

With regards to the manner of eating and filling the stomach, the Qur'ānic injunction is:

And eat (freely of clean, lawful foods) and drink (freely of clean, lawful beverages), and be not extravagant; surely $\mathrm{He}$ does not approve of the extravagants. \{Al-Quran, Surah al-A'rāf, Chapter $7: 31\}$.

With regards to the matter of Fear and Hope (جر و فوخ with Allah, Islam again teaches the principle of moderation --- neither letting its followers to become despaired of Allah's Mercy nor letting them to become heedless of His Wrath and Punishment.

The holy Quran quotes the words of Prophet Ya'qūb / Jacob (A.S.) when he said to his sons:

My sons! Go and ascertain about Yūsuf and his brother, and despair not of the Mercy of Allah; none despair of the Mercy of Allah except a people disbelieving. \{Al-Quran, Surah Yūsuf, Chapter 12: $87\}$

The sinners and the transgressors whose hearts are melted and are inclined to repent are thus affectionately addressed as:

Say thou (on My behalf, O Prophet!): my bondmen who have committed extravagance against themselves (by acts of infidelity and impiety): despair not of the Mercy of Allah: verily Allah will forgive the sins altogether (to those who sincerely repent and confess His Unity). Verily He! $\mathrm{He}$ is the Forgiving, the 
Merciful. \{Al-Quran, Surah al-Zumar, Chapter 39: $53\}$.

The most decisive Ayah (verse) in this regard is the following one:

Is he who is devout in the watches of the night prostrating himself and standing, bewaring of the Hereafter and hoping for the Mercy of his Lord to be dealt with like a wicked infidel? Say thou (O Prophet!): shall they who know and those who know not be held equal (in the sight of Allah)? It is only men of understanding who receive admonition. \{AlQuran, Surah al-Zumar, Chapter 39: 9\}.

It has been made clear in this Ayah (verse) that the attitude of true believers is in between two extremes; they are neither heedless of the wrath and punishment of Allah nor lose hope in His Mercy. Enumerating the noble qualities of true believers, Allah says:

Their sides leave off the couches (while yet there is night) calling upon their Lord in fear and in desire, and they expend of that with which We have provided them. $\{$ Al-Quran, Surah al-Sajdah, Chapter 32: 16\}.

\section{CONCLUSION}

Thus the principles governing Islamic way of life are highly balanced. They are free from either extremes. The Islamic teachings aim at establishing such a balanced human community which is free from excesses and deficiencies and steers away to the way which is moderate and justly balanced. This moderation is not seen in one or the two aspects only but it encompasses all the aspects of human life. From the above discussion it is clear that Islam has maintained the principle of moderation and equilibrium intact in matters related to the beliefs, acts of worship and adoration, mutual dealings and transactions, family and social life and even to the matters related to the international relationships.

This principle of moderation plays a threefold role in the human life. Firstly, it saves humanity from the detriments which are caused by the extremism, secondly, it is the basis for the establishment of a justly balanced human community which is prosperous and happy in all respects, thirdly, it safeguards humans from falling to the extremism pleasing to Satan that leads to astray from the straight path. Above all this upholding the principle of moderation propounded by the holy Quran is also the means of gaining the goodwill and pleasure of the Lord of the worlds.

\section{REFERENCES AND ENDNOTES}

1. The phrase may also be rendered as: 'We have exalted you, or ennobled you, as a nation conforming to the just mean; or, just or equitable, or good.' [Lane's 'Arabic-English Lexicon'] as quoted by Maulānā Abdul Majid Daryābādī in his Tafsīr, Tafsīr al-Quran. See Daryābādī, Moulānā Abdul Mājid, (English) Tafsīr al-Qur'ān (4 vols), Academy of Islamic Research And Publications, Nadwatul - Ulama, Lucknow-226007, India, 2011. Vol. 1, p. 93.

2. See al-Quran Surah Āl-i 'Imrān, Chapter 3, verse 110. The Quran says: You are the best community ever sent forth to mankind (to benefit it by your precept and practice, O Muslims!); you enjoin what is right and forbid what is wrong, and you believe in Allah.

3. Asad, Muhammad, Islam at the crossroads, Adam Publishers \& Distributors, New Delhi-110002, (India), 2011, p. 32.

4. Ezra of the Bible, whose official title in the Jewish tradition is the "Scribe of the words of the commandments of the Lord and His statutes for Israel' (Friedlander, 'Jewish religion', p. 125) and whose work constitutes a landmark in the history of Judaism. (Daryābādī, op. cit. vol. 2, p. 226).

5. Masīh literally is 'wiped over with some such thing as oil,' and Al-Masī (with the definite article AL) is 'the Anointed, the Christ.' Note that the holy Quran never disputes the title of Jesus to Messiahship. It is only his Divinity whether as Son or as Child or Incarnation that Islam so consistently denounces. (Daryābādī, op. cit. vol. 2, p. 227).

6. (A.S.): It is an abbreviation for Arabic " ملاسلا و "مولصلا هيلع " which can be translated in English as "May Allah's blessings and peace be upon him".

7. Palestine might at once have been occupied, or its conquest at any rate commenced, if the people had had faith. But, on the near approach of danger, their hearts failed them (Rawlinson, Moses: His life and times, p. 177). As quoted by Daryābādī, op. cit. vol. 1, p. 421.

8. (S.A.A. $\left.{ }^{W} . S\right)$ : It is an abbreviation for Arabic " ملسو "هيلع للها يلص" which can be translated in English as "May Allah's blessings and peace be upon him". It is necessary for a Muslim, and it a source of 
great reward for him to read "ملس و هيلع للها يلص" whenever Prophet's name is mentioned.

9. For better understanding of the Islamic injunctions related to the rahbāniyyah (asceticism / monasticism) see: Shafī', Muftī Muḥammad, Ma'ārif al-Qur'ān (8 vols; rendered in English by: Prof. Muhammad Shamim, Muhammad Ishrat Husain, Muhammad Walī Raazi, Moulānā Ahmad Khalil Aziz, Prof. Muhammad Hasan Askari), Farid Exports, New Delhi, India. Vol. 8, pp. 338342.
10. Daryābādī, op. cit. vol. 4, p. 331.

11. (Rad.A): It is an abbreviation for Arabic " "هنع للها يضر \اهنع المهنع English as "May Allah be pleased with him / her / both of them / all of them."

12. Quoted by Daryābādī, op. cit. vol. 1, p. 148.

13. Ibid. vol. 1, p. 148.

14. Ibid. vol. 1, p. 148.

15. Daryābādī, op. cit. vol. 1, p. 153. 